\title{
THE IMPACT OF GLOBAL FINANCIAL CRISIS UNDER THE ROMANIAN FINANCIAL MARKET
}

\author{
Ciuraru-Andrica Cristina, Teaching Assistant \\ UNIVERSITY OF BACĂU
}

\begin{abstract}
:
Today the most disputed subject is the global financial crisis. Laymen and experts say their point of view and wonder when and how will end this "apocalypse" of the financial world. But to understand it, it needs to make it the "radiology", to establish a "diagnosis" and of course an appropriate "treatment", which I tried to "build" in these few words.
\end{abstract}

Day in, day out, in the last time, we are assault by a subject that seems endless: financial crisis. It search for reasons, solutions and, why not, for guilty, and finally, when and how it will end this wave that floods, merciless, many regions of Earth. Of course, some countries floating above the wave, others are struggling with it, while some sit and watch that the wave is not black as it seems. Yet the reality is dismal, at least as experts argue, because it is obvious that not everyone "suffering" the same extent from the so-called "global crisis". Some say that the rich would have the most to lose, the others that the poor people is most affected, but the truth it feels each of us "by how much and when we need to pull out from our pocket". And yet, for the laymen, the subject is useless, an endless excuse for the bad course of Romanian society, because anyway we were not better before the crisis, so haw hard we will whit it? But is it so? Of course, the most in the field could not accept that. There must be an explanation for everything, right? So the global crisis has a story too, but before we relate it, let us make familiar this term.

Because the subject is so noted, is even a site dedicated exclusively to it, called www.crizafinanciară.ro. Here we find out that the financial crisis is a term attributed to the situations in which institutions or financial assets suddenly lose a significant part of their value. It is the reality we are witnessing. Moreover, the current crisis has also a name apart: the subprime crisis, because it is caused by a sudden decrease of the liquidities on the financial markets, caused by the failure of companies that invested in mortgages subprime (whit high risk). Its causes seems that have a beginning since the end of last century, but the top of her was reached in 2007 and 2008, when the crisis has brought to light serious deficiencies in the global financial system and regulatory framework. And yet, if it comes up such signals that notice a future crisis, why do not have taken an attitude? However, now is too late, so us are left only to see where the crisis began, why, what adverse effects brought with her and, of course, how to get out as "least affected" in it.

The story of financial crisis begins like this:

Once upon a time (and of course, still is) a dream land bearing the name of the United States. Many people dreamed to be here, where the welfare were at every step. At least some think so! Anyway, in such a strong and stable economy in a bad year, 2008, with a history course in preceding years, when more and more Americans no longer paid mortgage loans, causing the first bankruptcies of banks specialized in these products, is happened the decline of American banking systems that is propagated everywhere in the world and then began the decline of stocks exchange also. From here until the crisis of the entire U.S. financial market and a global one too, there was only one step. Why that? We all know how big were the U.S. influence at least over the majority of the countries. So how "the spark" was light up from the base, "the fire" touched the many countries, more or less dependent on the U.S.A. In this way we could say we found the culprit. But why is it guilty if in all this time managed to dominate the economy of so many countries and that they now are "sisters in suffering" whit it? 
However, in an article on 11 October 2008 of the Cotidianul newspaper, Adrian Deoanca blame Alan Greenspan, chairman of the U.S. Federal Reserve from 1987 to 2006, for the outbreak of financial crisis, whose opinion mattered very much in state control of financial market and the using of financial derivatives contracts. They are identified by a contract through one part receives money in exchange of the promise to buy or sell goods or services at a specified time in the future. Thus, for a small amount and with a mortgage warranty, an investor can control a higher percentage of shares of a company. These contracts, however, promise to protect the investors from wastage, which has stimulated them to take risks much higher. So they have allowed to assume more mortgages and made bigger loans into account of a future increase. Greenspan considered the derivatives contracts "excellent vehicle to transfer risks from those who do not have to take them to those who are willing and able to do so", but in the opinion of others, were considered "financial weapons of mass destruction hiding danger that can be lethal"(Warren Buffet), or even potential "H-bomb" (Felix Rohatyn). All this, in conjunction with more and more lax standards for the approval of mortgage loans, a significant increase of loan incentives (reasonable original terms) and a long-term trend for increasing the price of houses, had determined the American people to ask for burdensome mortgage loans, which evolution was wrong anticipated and that brought him into deadlock. So broke out a "real boom" that was the "spark" of global crisis. From now on follows a whole series of events whose "rein" may not be taken.

Therefore, many economists argue that, if Greenspan would have acted differently in his career, the present crisis of the American economy, could not be exists.

And yet: one man to blame for this crisis? We don't believe it! But everything is possible!

Very interesting, I found it, the vision of an author named Alexander Gamanji from Moldova republic, about the world economy, captured in an article published on the website of the Independent Analytical Center Expert Group. He compares the world economy with a turned pyramid. The bottom of the pyramid represents the volume of goods and services, served by cash or non-cash to about 50 trill. USD annually, and the top of it represents the financial derivative securities like all sorts of shares, bonds, treasury bills, etc. The top is about 10 times higher (500 trill. USD) than the bottom, exceeding 10 times the prices of goods and services produced, and for that the author asks him self if this huge bulk of financial derivatives, (fear of international financial stocks too) will fall. The answer has come!

Our story continues with the bad consequences which had the collapse of many important banks of U.S.A. and the intervention of the state to save others, equally important: panic, desperation and unique moments, in a single word: crisis. Lehman Brothers' bankruptcy and Merrill Lynch' purchase by Bank of America, nationalization of banks Fannie Mae and Freddie Mac, rescuing giant AIG and Citigroup by the American government, collapse the financial world. As well it adds the pull down of the American auto industry, which means one step to a total collapse.

However the situation was temporary saved and "the air" which was missing from the U.S. financial market, "the liquidities", was injected at the last minute of the Central American Federation of Banks (Fed). Liquidity crisis has extended of course in Europe too, where the European Union, the International Monetary Fund and World Bank have made steps to calm down the situation. In particular, states have begun to issue plans to save their financial institutions.

Indeed, quite unexpected events that have affected virtually the whole world and whose effects were felt everywhere and unfortunately, in Romania too, especially at the Bucharest Stock Exchange, with dramatic decreases of index, which reached minimum historic untouched by two-three years. These events stirred panic among native and foreigner investors, who emphasized the BSE crisis, which is under the sign of uncertainty and volatility. It was necessary even a suspension of BSE activity, as a measure of protection against excessive fall of stock index. All this took place in October 2008, 
considered by some "fatal month of the financial world" (Rareş Şofariu, director of research and development of KD Capital Management, in an interview for Wall-Street). After such a shock, stock market has begun to recover, with ups and downs, but it is clear that for a total return should past a while. Until then stock remains very sensitive being easily influenced, even investors acting instinctively and emotionally.

In Romania, however, the crisis is felt not only at the Stock Exchange but also in the banking sector, where near the losses of banks listed on stock exchanges were harden even the terms of the loans by raising interest rates and the volume of file credit. And yet the crisis is in favor to those who have savings, whose storage would make a much bigger gain. Since banks need liquidities, interests rate on deposits have increased considerably. In this way, the population has not resorted to massive withdrawals from bank accounts, which has accentuated the gravity of the situation. Also Romanian banks access to external sources of funding (in principle for the foreign banks' subsidiaries) has a considerable decrease, which led to the measures specified above.

Also we are witness of an extraordinary depreciation of Romanian leu against the euro and even against the dollar, a problem quite serious, with adverse consequences on the Romanian economy and of course over the people who bitterly notes how the bills are "fat" over night, and loans in foreign currency simply "get crazy." Moreover the situation seems to have a bad ending, the analysts arguing a continuing depreciation of the Romanian leu, which is common with other currencies of European countries. This has negative repercussions also on the Romanian real estate market, which is in full decline whit trends return, because the banks have hardened the terms particularly for mortgage loans. But for the population, the decrease of houses' price is more than welcome, especially as we all know how "huge" they have been so far.

The crisis has given "slogs" to the National Bank of Romania which had to save the situation interfering opportunely, but success was not the expected one because the depreciation of the Romanian leu continues.

As well we are witness, unfortunately, to a wave of dismissals, technical unemployment, reductions of production, etc., cruel consequences of the crisis. So a part of the population is seriously affected and felt fully the effects of the crisis. This may cause an increasing of indebtedness of those who already have banks loans, and implicitly a danger for the credit institutions, by an acute absence of liquidities. Since the consumption also fell very much, many firms are threatened with bankruptcy. The series of negative effects may continue.

However, according to a report by the World Bank as regards the global economic prospects in 2009, Romania has the chance to avoid recession, which will affected many countries. Our country will accounting even for economic development, but the financial crisis will not pass without leaving traces it too. Anyway, the opinions are divided, but how will be, will see it than.

One obvious reason of extending the crisis is the globalization which now shows its advantages and disadvantages. But of course these are no longer taken into account viewing her big advantages. Though, the expanding of transnational companies has determined that the problems faced by the mother on the original country to be reverberated also to their subsidiaries and on markets in which they operate. This is obvious to us, at least in the banking system, but not only. So the crisis gets access anywhere.

"Financial apocalypse", as was called the crisis in an article signed Antena 3, requires action anti-crisis. Our country has made efforts in this regard, starting whit some changes of Fiscal Code. It is about the suspension of tax payment regarding the transactions on the capital market and also the revenues like interests for term deposits and/or savings instruments, fiscal incentives for research, development and innovation, reduced rate of VAT at five percentage points, for housing delivery as part of social policy and other measures such as suspension of the tax pollution, EUR1.000 for each unemployed worker hired, reducing social 
insurance contributions by 10 percentage points in the next four years, not taxing the reinvested dividends, a five percentage points allowance for taxpayers who pay their taxes 10 days earlier than the term, measures to support small and medium enterprises, etc. Certainly these are measures taken at national level but each company individually could take its own measures anti-crisis.

Many peoples argue that the signs of outbreak of this crisis were known earlier, but nobody wanted to read them, they have been ignored. Today we suffer the consequences. There are experts who say that such crises are ordinary because they restore the deficiency mechanisms. Sounds like a consolation, but nobody knows the truth. However the national and international financial institutions will have to review the regulatory framework because at the time of crisis he has revealed its deficiencies.

\section{References:}

[1] www.antena3.ro

[2] www.capital.ro

[3] www.euractiv.ro

[4] www.expert-grup.org

[5] www.mediafax.ro

[6] www.standard.ro

[7] www.wall-street.ro

[8] www.ziare.com
Even if from the crisis outbreak until today, the situation has come down, the future is not well at all. It takes time for the effects of crisis to be forgotten and even removed, but certainly 2008 will go down in history as an year "that has collapsed all ideologies and economic doctrines and reworded the top of world giants." (Diana Cioltei, in an article) 